\title{
Constance Garnett's Translation of Leo Tolstoy's The Kingdom of God Is within You
}

\begin{abstract}
This article explores Constance Garnett's work on Tolstoy's famous treatise The Kingdom of God Is within You as well as on his other works. Through various archival materials from the Tolstoy museums in Moscow and at Yasnaya Polyana, the paper traces Constance Garnett's thorough and hard work, and her communication and collaboration with Leo Tolstoy. The article also gives a picture of how The Kingdom of God Is within You was published and reviewed in England and in the US. There are some contradictions concerning where the meeting between Leo Tolstoy and Constance Garnett during her visit to Russia in 1894 took place. According to archival materials and Tatiana Tolstoy's diary, her only meeting with Tolstoy took place on 12/24 January, and it was in Moscow, not at Yasnaya Polyana as some critics say. The article points out the growth of interest in Tolstoy in England in the last decades of his life.
\end{abstract}

Keywords: critics, editions, novels, publishers, religion, reviews, Russian literature, translation, treatises, versions

\section{Introduction}

Constance Garnett (1861-1946) originated from a family of which many generations were connected with Russia in various ways. That country was not a complete terra incognita for Constance. Her friendship with Russian political emigrants played a very significant role in the growth of her interest in Russia. Among them were Felix Volkhovsky, Prince Peter Kropotkin, and Sergei Stepniak. All of them were frequent guests at the hospitable house of Edward Garnett, who married Constance in 1889. This friendship influenced her literary tastes and attracted her to Tolstoy's works. Before her acquaintance with Russian emigrants, Constance Garnett was a librarian of the People's Palace; she also participated in the activities of the Fabian Society. She was well prepared for communication with the Russian emigrants and the subjects they could have raised in their discussions. It is important to note that Stepniak was greatly interested in Tolstoy's works and lectured on him abroad. It was Sergei Stepniak who advised Constance Garnett to learn Russian and translate Russian literature professionally. All her Russian friends helped her in her Russian studies - especially Felix Volkhovsky, 
who was the editor of Free Russia from 1890 to 1914. Even before their friendship with Russian emigrants, Edward and Constance Garnett were interested in Russian literature and read some of the Russian authors. Of course, they were familiar with Tolstoy's works or heard about them. There are some contradictions about where the meeting between Leo Tolstoy and Constance Garnett during her visit to Russia in 1894 took place. According to the archival materials and Tatiana Tolstoy's diary, her only meeting with Tolstoy took place on 12/24 January, and it was in Moscow, not at Yasnaya Polyana as some critics say.

\section{Two English versions of The Kingdom of God Is within You}

In 1894, William Heinemann published in London the translation of Leo Tolstoy's treatise The Kingdom of God Is within You. The translator was Constance Garnett, who was just beginning her career as a translator of Russian literature. At the same time, another version of this treatise in the translation of Aline Delano was published by the Walter Scott publishing house. The influential Heinemann tried to stop the Walter Scott publication of The Kingdom of God Is within You, announcing that he was the only one in England who had exclusive permission to publish this book. That was not completely true, and his attempt to stop the publication was not successful at all, so both versions of The Kingdom of God Is within You received their share of criticism. (It is worth mentioning that the dispute over publication of the treatise took place after Tolstoy's rejection of his copyright!)

One of the Academy's reviewers read French and German versions of the treatise, and in his review he compared the two English translations. In his opinion, Aline Delano did not understand properly what Tolstoy was trying to say in his work. His comparison was definitely in favour of Constance Garnett; even Delano's translation of the subtitle, "Christianity not as a mystical doctrine, but as a new life-conception" was "very Teutonic" in comparison with Garnett's "Christianity not as a mystical religion but as a new theory of life," which was "intelligible” and in "sensible English" (quoted in R. Garnett 1991, 132-133).

Tolstoy was quite satisfied with Constance Garnett's translation, and in one of his letters to Edward Garnett several years later, in June 1900, did not hesitate to mention again how highly he appreciated her translation: "My kind regards to your wife, and I take opportunity of once more thanking her for her excellent translation of 'The Kingdom of God Is Within You'” (Tolstoy 1928-1958, 73: 397). Aylmer Maude (1910, 609), Tolstoy's biographer and translator, mentions how highly Tolstoy appreciated the translations of Constance Garnett among the Eng- 
lish translations of his works. After her work on The Kingdom of God Is within You, Constance Garnett began to translate Tolstoy's novels and stories. Why did this young teacher of classical languages - a librarian at the People's Palace and a graduate of Cambridge University - become so interested in the almost unknown Russia and its literature? What made her pay attention to this very complicated religious and philosophical work by the Russian writer Leo Tolstoy?

\section{Tolstoy in England}

The second half of the 1880s was a period when, in the UK as well as the US, there was a definite growth of interest in Tolstoy's works. Henry James wrote in 1896: "The perusal of Tolstoy - a wonderful mass of life - is an immense event, a kind of splendid accident, for each of us: his name represents nevertheless no such eternal spell of method, no such quiet irresistibility of presentation, as shines, close to us and lighting our possible steps, in that of his precursor" (quoted in May 1994, 23).

Literary journals like Quarterly, Westminster Review, and some others testify to the interest in Tolstoy. In 1887, in the Fortnightly Review, the article "Count Leo Tolstoi” by the well-recognized English poet and philosopher Matthew Arnold was published (Arnold 1887). ${ }^{1}$ In 1888, Charles Turner's book Count Tolstoy as Novelist and Thinker appeared (Turner 1888). Tolstoy's works became so popular in England that Turner was invited to London, and then to Oxford in 1889 to lecture on Tolstoy. In the 1890s, Tolstoy's correspondent and visitor Edward Kenworthy, with his Brotherhood Publishing Company, in cooperation with Tolstoy's friend and collaborator Vladimir Chertkov, published some of Tolstoy's works, mostly of religious character. In Tolstoy's personal library there is a book called The Christian Teaching by Leo Tolstoy with a publication date of 1898 (Biblioteka L'va Tolstogo 1999, 2: 439-440). In 1898, Kenworthy also published Tolstoy's treatise What Is Art, translated by Aylmer Maude (Biblioteka L'va Tolstogo 1999, 2: 484). Tolstoy presented a copy of this book to his wife Sophia Andreyevna, and it has been kept in his personal library.

There are thirteen books written by Kenworthy in Tolstoy's library; some of them were published by Kenworthy's own publishing house (Biblioteka L'va Tolstogo 1999, 1: 565-568). Tolstoy was very impressed with the scope of Kenworthy's religious activities in England and thought highly of his English correspondent

1 In 1861, while in London, Tolstoy received a letter of recommendation from Matthew Arnold for visiting some London schools, the Saint Mark's Practising School in Chelsea in particular. 
and friend. In a letter to Kenworthy, he wrote on 5 March 1894: "I feel in you a kindred spirit and it is a joy for me to be in communication with you" (Tolstoy 19281958, 67: 61). In his Tolstoy: His Teaching and Influence in England, Kenworthy wrote:

It seems to me that at the present time there is not living a more commanding personality and profounder spiritual influence than Leo Tolstoy, the Russian. [...] There is an increasing number of people who profess to find in his teaching inspiration and guidance of the truest kind. These opponents and these adherents of Tolstoy, are, perhaps, more numerous in England than in any country outside Russia. (Kenworthy 1901, 2)

He develops this theme in his book Tolstoy: His Life and Works:

Tolstoy's reversion to "the Christianity of Christ" has a peculiar force of appeal in England. It may, perhaps, be said, that men of our nation, of all others, have most and best witnessed for the extreme truths which Tolstoy now declares. [...] I hold, from personal knowledge, that in the minds which provide what religion has, Tolstoy touches the same springs that were reached by Wicklif, Fox, Bunyan, and Wesley. His more obvious work is done in Russia, but his inspiration is working here, and will work. (Kenworthy 1902, 38-40)

Summing this up, Kenworthy writes: "In now treating of Tolstoy's influence in England, we must remember that our subject occupies only a small place in outward public regard, and becomes of high importance only to those who know that spiritual life in individuals and nations is the true and only life" (1902, 41). In his letter to Kenworthy of 15 May 1894, Tolstoy wrote: "I think that our task is to let people feel that in this life they have nothing else to do - as to help in the establishment of the Kingdom of God, which cannot be established otherwise, than by establishing it in our own hearts by trying to be as perfect as is our Father in Heaven" (1928-1958, 67: 127). In his book, Kenworthy replies to Tolstoy's idea of “The Kingdom of God”: 'In seeking 'The Kingdom of Heaven' of Jesus, Tolstoy, of course, contemplates the entire supplanting of the existing social system by a better, the ideal one. But his methods for bringing this about are how different from those of the revolutionaries!” (Kenworthy 1902, 41). Going to visit Tolstoy in 1895, Kenworthy wrote in his book A Pilgrimage to Tolstoy: "For I am to see Leo Tolstoy and friends of his; to arrange with them ways and means of carrying forward in England the work to which they in Russia give themselves" $(1900,1)$.

Beginning in 1900, Vladimir Chertkov, Tolstoy's friend and collaborator, being in England, began to publish Tolstoy's religious and philosophical works (especially those which were prohibited in Russia) in his Free Age Press. 


\section{Constance Garnett working on The Kingdom of God Is within You}

That was the background for Constance Garnett's work on the translation of Tolstoy's treatise. Constance Garnett began to work on the treatise The Kingdom of God Is within You at the end of 1893, when the first period of "acquaintance" with Tolstoy's fiction was almost over in Britain, and British readers were turning their attention to Tolstoy's religious and philosophical works as well as to his fiction. Constance Garnett was working for the famous London publishing house of William Heinemann, who bought the copyright for the translation of the treatise from the Bibliographical Bureau in Berlin. Heinemann had to inform Tolstoy about it in a letter of 13 January 1894, rejecting the assumption pronounced by the Daily Chronicle, in its correspondence from Russia, that the translation was being made from some poor French version. Tolstoy kindly replied: "I was very glad to know that the translation had been done from Russian and hopefully it will be good" (Tolstoy 1928-1958, 65: 15).

Material from the archives of the State Museum of Tolstoy in Moscow and archival materials of Constance Garnett's grandson, Richard Garnett, testify to the fact that she finished her translation of the treatise before her trip to Russia in January 1894. She worked really hard and had to postpone the translation of Turgenev's works. Stepniak participated in work on the translation of The Kingdom of God Is within You, and he helped Constance Garnett with the introduction to the treatise. She wrote about her work on translation thus: "Tolstoy's style in his religious and philosophical works differs considerably from that of his novels. He no longer cares about the form of his work, and his style is often slipshod, involved, and diffuse. It has been my aim to give a faithful reproduction of the original" (quoted in R. Garnett 1991, 112). Some extracts from The Kingdom of God Is within You were already published at the end of 1893 in the New Review. Unfortunately, this was done without Constance Garnett's permission.

\section{Constance Garnett visits Russia and Tolstoy}

On 1 January 1894 (20 December 1893), Constance Garnett left for Russia. She arrived in St Petersburg in order to deliver money collected in London for the famine in Russia. One of her primary aims in Russia was to perfect her spoken Russian. Nevertheless, after a month she wrote with disappointment and excitement: "I still cannot follow a conversation in Russian, and can speak only a little better than when I came. But I have learnt and seen so much of Russian life that I feel I 
could hardly have spent my time better. And I have made such nice acquaintances that I shall want to come to Russia every year” (quoted in R. Garnett 1991, 130).

We know about Constance Garnett's travels in Russia from the Russian newspapers. On 3 January 1894 (23 December 1893), the St Petersburg newspaper Novosti informed its readers about a young English translator's visit to Russia. Somehow, she was called by mistake a daughter of the well-known poet Richard Garnett (in fact, she was his daughter-in-law). On 15 February 1894, the newspaper Russkaya zhizn' published the article “An English Traveller in the Nizhnii Novgorod Region” by Vladimir Korolenko.

Constance Garnett was very busy with the money collected for the famine in some regions of Russia. She was also supposed to meet various people in Moscow and Petersburg, but in spite of her very tight schedule, she still managed to visit Leo Tolstoy at his home in Khamovniki: "He made a great impression on everybody who saw him for the first time. His piercing eyes seemed to look right through one and to make anything but perfect candour out of the questions; at the same time there was an extraordinary warmth and affection in them" (quoted in R. Garnett 1991, 122). She told him about her work on The Kingdom of God Is within You, and about the difficulties she had to overcome as a translator. She was deeply touched by her reception in the town house of Tolstoy, where she also met some members of his family, including his wife Sophia Andreyevna and his eldest daughter Tatiana. She informed her husband that Tolstoy was not only looking forward to the publication of her translation of the treatise but also wanted her to translate his fundamental philosophical and religious work, which would be later known as The Four Gospels Harmonized. Tolstoy also remarked that he liked the English translations of his works much better than the French. Constance Garnett felt a great deal of responsibility. Tolstoy's suggestion about his new work put Constance Garnett in a very difficult situation. It was a real challenge for her, as William Heinemann would not have published anything like this work. On the one hand, she was obviously flattered to receive such an offer from Tolstoy himself; on the other, she had some serious doubts about her publisher Heinemann, who would not publish a purely theological book. After her trip to Nizhnii Novgorod, she came back to Moscow on 12 February to meet Tolstoy again, but he had left for Grinyovka, his son Il'ya's estate. On that day, she sent a letter from the hotel Rossiya to Sophia Andreyevna Tolstaya: ${ }^{2}$

I called yesterday in the hope of seeing Count Tolstoi \& was disappointed to hear that he is in the country. [...] I am sorry to say that Mr. Heinemann is not willing to undertake that work -

2 The correspondence between Constance Garnett and Leo Tolstoy was exclusively in English. 


\begin{abstract}
the translation of the Gospel with Commentary as he publishes nothing of a purely theological character. I am pledged to do other work for Mr. Heinemann, so that I could not translate for another publisher for some time to come. S. I am obliged to give up the idea of translating it as I could not hope to begin it this year. I am very sorry to give it up - especially as several translations of Count Tolstoi's works are very poorly done indeed and give a very distorted idea of the original. About the other book I will write to Count Tolstoi after seeing Mr. Turner in Petersburg in a few days. (Manuscript Department of the State Museum of L. N. Tolstoy, f. $1-216 / 29)$
\end{abstract}

Before leaving for England, she had seen Charles Turner in Petersburg, and, on 19 February 1894, she wrote to Tolstoy about their meeting. Turner agreed to do the translation of Tolstoy's The Four Gospels Harmonised:

\begin{abstract}
I saw Mr. Turner to-day \& consulted him about the translation of your next book. He would like to see it before deciding and then if he finds it would not be prudent to translate it he will forward it to me. I spoke to him of the version of the Gospel with Commentary which I am very sorry I could not translate at present, as Mr. Heinemann could not, I think, publish a purely theological book and I am pledged for the next few months to work for him. Mr. Turner asked me to tell you that he would gladly translate your version of the Gospel and would undertake to get it published in England. [...] I am very glad to hear that Царство Божіе is arousing great interest \& has been sympathetically reviewed and will try to collect some of the notices and send to you with my translation from England. (Manuscript Department of the State Museum of L. N. Tolstoy, f. 1-216/28-1).
\end{abstract}

We have to admit that Constance Garnett saw herself only as a translator of Tolstoy's treatise: her purpose was to present an adequate translation, but not to defend his religious doctrine. On the envelope of this last letter there is a pencil note by Tolstoy: "БО," which means: "No Answer." In his letter to Kenworthy on 5 March 1894, Tolstoy wrote about Turner's work on the Gospels: "My book, the translation of the Gospels, is now being translated by a gentleman in Petersburg Prof. Turner” (Tolstoy 1928-1958, 67: 62).

Her only meeting with Tolstoy took place on 12/24 January, and it was in Moscow, not at Yasnaya Polyana as some critics say. Tolstoy was at Grinyovka until 1 February (old style), on 2 February he left Grinyovka for Yasnaya Polyana, and on 11 February he came back to Moscow. S. Constance Garnett could have visited him at Yasnaya Polyana only in the period from 2 February to 10 February (old style). That was hardly possible, as on 7 February she was already writing to him from St Petersburg. It was also hardly possible that she visited Yasnaya Polyana during the period of 2-5 February: there are no entries about it either in Tatiana Tolstoy's diary, where she mentions all the visitors, or in Tolstoy's diaries and letters, or in Constance Garnett's letters, in which she describes her visit to Tolstoy at his Moscow house. In 1904, she undertook another trip to Russia but unfortunately was not able to see Tolstoy. 


\section{How was The Kingdom of God Is within You reviewed in England?}

During Constance Garnett's visit to Russia, The Kingdom of God Is within You was published in England, followed by many reviews. On 27 September 1894, Constance Garnett wrote to Tolstoy:

I have been much disappointed by the reception of the book here. Everything you write is eagerly read and reviewed but I have not seen notices of it that showed a genuine appreciation of its spiritual meaning. It is difficult to measure its influence by looking at newspaper criticism. It was attacked by clergymen of different denominations in the New Review of which I send you a copy. The fact of its being attacked shows that its power was felt and dreaded. (Manuscript Department of the State Museum of L. N. Tolstoy, f. 1-216/28-2)

In her letter, Constance Garnett was also trying to explain how she was doing her best translating his work: "I am hoping you will like my version. I have tried to keep more closely to the original than is usually attempted in English translation from Russian. It is disfigured to my mind by the headlines which were composed and added without my sanction when I was out of England" (Manuscript Department of the State Museum of L. N. Tolstoy, f. 1-216/28-2). She also informed Tolstoy that she was sending him a copy of the book, The Kingdom of God Is within $Y o u$, along with the letter, through some English firm in Moscow. It is unknown if he ever received the book; it has not been preserved in his personal library. His library does, however, contain another English version of the treatise: The Kingdom of God Is Within You, or Christianity not as a Mystical Doctrine but as a New LifeConception, revised and corrected translation by V. G. Chertkov (London: The Free Age Press, 1900? [Biblioteka L'va Tolstogo 1999, 2: 454]).

Of Constance Garnett's translations, Tolstoy's personal library contains Anna Karenina (London: Heinemann, 1901), Ivan Ilyich and Other Stories (London: Heinemann, 1902), and War and Peace (London: Heinemann, 1904 [Biblioteka L'va Tolstogo 1999, 2: 435, 458, 483]). Besides these editions, in 1908 she translated Tolstoy's short military story "The Raid” in a very short time; the story was published in the first issue of the new literary journal English Review (1908). A copy of it has been preserved in Tolstoy's personal library at Yasnaya Polyana.

In the letter quoted above, Constance Garnett wrote about how Tolstoy's articles were received in England:

An article of yours on the Franco-Russian alliance which appeared in installments on three successive days in the Daily Chronicle did, however, create a great deal of attention, and has left its mark on public opinion. To appeal direct to the people through the newspapers is a very satisfactory method; I should advise you to make as much use of it in England as you 
can. Through the newspapers, ideas reach an immense public, who would never meet with a book on the same subject. (Manuscript Department of the State Museum of L. N. Tolstoy, f. $1-216 / 28-2)$

It is obvious from that letter that Constance Garnett was still curious about Turner's translation of Tolstoy's work:

\begin{abstract}
I saw from a newspaper the other day that Mr. Turner is already "at work on the forthcoming great social novel", so I imagine he has decided to undertake the translation after all, and does not intend to send it to me. I am sending you one of the two reviews, and a book of prose poems, "Towards Democracy", in which seem a good expression of the appreciation of a section of our younger generation. I beg you not to trouble to acknowledge this. I shall hear from my friends whether my parcel reaches you safely. (Manuscript Department of the State Museum of L. N. Tolstoy, f. 1-216/28-2)
\end{abstract}

On the envelope of this letter there is a pencil note by Tolstoy in Russian: “Адресъ списать," which means: “Address to be copied.” In Tolstoy's personal library, there is a copy of Edward Carpenter's book Towards Democracy (1892), signed by Carpenter in 1896 (Biblioteka L'va Tolstogo 1999, 1: 203-204). We do not know if it was the copy sent by Constance Garnett. As for the review, it has been preserved in the Manuscript Department of the State Museum of L. N. Tolstoy in Moscow, along with the letter. The review says:

Tolstoy offers to this sick world what he conceives to be the healing balm of true Christianity, the purifying remedy which Christ brought to suffering humanity. This remedy is not very similar to that presented in most of our churches under the Christian name. It is, in a word that, instead of speculating about Christ, and giving mystic interpretations of transcendental doctrines, we should set before us the task, hard and uphill at first, of actually living Christ's life, of obeying his commands literally. We are to enter on a vita nuova, in which we are to live by love - the one sole bond of union which can keep us together, and which can solve our problems and give peace to our lives. The Sermon on the Mount is to constitute for us a veritable series of commands to be obeyed here and now, obedience to which will issue in social health and personal joy and satisfaction. Does anyone say that, in our actual civilization, the Sermon on the Mount cannot be literally obeyed? But what if this civilization itself is perishing of dry-rot? What if the one thing needed to save us is its overthrow, not by violence and revolutions, but by the sure solvent of ideas actually carried into life? The "kingdom of God within us" will alone abolish the kingdom of this world which now exerts its power over our lives. Such is the substance of Count Tolstoi's latest message to his time. (Manuscript Department of the State Museum of L. N. Tolstoy, f. 1-216/28-2)

The author of the review remarks: "All that Tolstoi writes, penetrates with the power of absolute sincerity through the crust of convention and make-believe, in which nearly all of us live, to the central core of our life.” The author underlines how accurate Tolstoy was in his treatise, which draws parallels with the situation 
in England: "As a result, the Church itself blesses war; bishops compose special prayers asking God to bless a particular body of professional fighters; war trophies bang up in sacred edifices, and in England, at least, bishops use the pulpit to glorify disgraceful wars out of which they expect to reap pecuniary profit.” The reviewer quotes a great deal from Tolstoy's treatise:

There are three views of life, says Tolstoi: the animal, the social, and the divine. The man who adopts the divine life-conception makes, not a mere social instinct, but love of the Supreme Good the ruling motive of his life. He conceives life itself "as taking its rise in the eternal life of God, and to fulfil His will he is ready to sacrifice his personal, family, and social well-being". This is true Christianity. And here follows a vigorous onslaught on the Positivist theory, which tries to found a social doctrine on an "abstract conception of man", for "humanity as a concrete conception is impossible". (Manuscript Department of the State Museum of L. N. Tolstoy, f. 1-216/28-2)

The reviewer agrees with Tolstoy that "the present age of humanity has outrun the Pagan life-conception, and can only be satisfied by the Christian life-conception, and yet the old Paganism is all about us, making our life false and unhappy." Analysing the chapter devoted to a consideration of the attitude of educated men towards war, the author of the review notes:

From that we proceed to the military conscription which is considered not as an accident, but as the extreme limit of the contradiction contained in the social life-conception. Here Count Tolstoi's extreme theoretical Anarchism comes in, for he boldly asks whether the State is needed at all. This question, however, cannot be decided on mere grounds of utility. "It is decided irrevocably and without appeal by the religious consciousness, by the conscience of each individual, to whom no sooner does military conscription become a question than it is followed by that of the necessity of the State". But here Count Tolstoi does not consider the position of the theoretical Anarchist like himself in a society which still believes in the State founded on force as ultima ratio. (Manuscript Department of the State Museum of L. N. Tolstoy, f. 1-216/28-2)

The reviewer calls the book "earnest and searching," underlining that it is "written out of the heart of a very great and good man." In the end, the reviewer concludes:

It is not difficult to criticize some aspects of it. It is evident that it is tinged throughout by consideration of special Russian circumstances. To us it seems that, in some form or other, the State (not the actual State, but the State in its essential conception) must continue to exist expressly for the purpose of preserving that freedom of action necessary to make Christianity a beneficent power. Anarchy for many generations to come will mean despotism. But it is not our purpose to criticize this noble utterance of a real prophet. It is enough that we have set forth briefly the means by which Tolstoy conceives that "the kingdoms of this world may become the kingdoms of Our Lord and of his Christ". (Manuscript Department of the State Museum of L. N. Tolstoy, f. 1-216/28-2) 
The treatise touched the hearts and minds of English readers. They might have liked or disliked the work of Tolstoy, but there were no indifferent readers. One modern critic has remarked that "the translator is the servant of the receiving culture, essentially a soldier called to heroic battle ('yeoman service', as Moser says of Garnett) in the cause of transporting, or importing, another culture" (May 1994, 37). Constance Garnett, while translating The Kingdom of God Is within You, was indeed a "soldier called to heroic battle."

\section{Garnett's intensive work on Tolstoy and other Russian writers}

Upon her return to England on 24 February 1894, Constance Garnett devoted herself to the translation of Russian authors. She translated the works of Turgenev, Dostoyevsky, Gogol', Chekhov, Hertsen, Goncharov, and Ostrovsky. As Kornei Chukovsky remarked, she "translated seventy volumes of Russian classical literature” (1966, 501; my translation). Her manner of translation from Russian was still taking shape at that time. Her grandson Richard Garnett describes the process:

\footnotetext{
She would read through the Russian, looking up the unfamiliar words and phrases and noting the English in pencil between the lines, just as she had done in her Greek books at Cambridge. Russian novels were usually paper-bound, and by the time she had finished with them they were often just a stack of loose sections. Then she would set to and write out the translation fairly rapidly. (R. Garnett 1991, 133)
}

Her father-in-law, David, in The Golden Echo, once noted that her face could be so expressive that "I could guess at the emotional tension of what she was reading” (D. Garnett 1953, 53-54). D. H. Lawrence was very impressed by her routine of translation: "sitting out in the garden turning out reams of her marvelous translations from the Russian. She would finish a page, and throw it off a pile on the floor without looking up, and start a new page. The pile would be this high ... really almost up to her knees, and all magical" ("Interview with Kyle S. Crichton" 1925).

In 1901, Garnett was working on Anna Karenina. There were several English versions of this novel, including the one by Nathan H. Dole published in 1886 in New York. Although Heinemann was very doubtful about the novel, Garnett began to work on it because, since 1896, when she had first read it in Russian, she had simply dreamed about translating it. Fanny Stepniak helped her in her work on this translation. Her Russian friends spoke of the high quality of her translation of Tolstoy's novel. 
In 1904, her translation of War and Peace was published. She tried to avoid the Russianisms, for example by using porridge instead of kasha, and by translating the words of the Governess of Voronezh, “ведь у Софи ничего нет,” as "Why, Sophie hasn’t a farthing” (Motyleva 1978, 95). Edward Garnett, her husband, who was in correspondence with Tolstoy too, participated in the process of translation. After she finished her work on the translation of the novel, she almost lost her eyesight, although she had been short-sighted since her childhood. Constance Garnett wrote about Tolstoy's style in The Art of Translation: “Tolstoi's simple style goes straight into English without any trouble. There is no difficulty" (1947, 195). She was probably satisfied with her translation of War and Peace, since at the end of her life she once remarked: "I should like to be judged by my translation of Tolstoy's War and Peace” (quoted in R. Garnett 1991, 205).

Of course, for the most part Constance Garnett managed to bring English readers as close to Tolstoy's novel as possible. Some critics say that she ignored the foreign text in the novel: for the most part, she translated into English all the French speech in the novel. Some critics, including Aylmer Maude, Tolstoy's biographer and translator; Henry Gifford; and Tamara Motyleva, a Russian scholar, mentioned her changes to Tolstoy's syntax, to some folk-words and expressions, and so on (R. Garnett 1991, 205-206). But even Gifford, comparing her manner with that of the Maudes, wrote: "the appeal of Constance Garnett consists in her sensibility. She can write with a delicacy of touch which the Maudes, for all their diligence and good sense, seldom achieve. This shows particularly when she hits on some phrase so apt as to seem definite" (Gifford 1978, 21).

The last letter to Tolstoy was written on 6 June 1900 by her husband Edward on behalf of both of them:

My wife and I have been asked to write an article on your novel Resurrection for Harper's Magazine, with the proviso that you should send a message to the American People, to be printed in the same number of [the] Magazine in which our article appears. I do not know that you wish to send any message at all to the American People, but should you do so, I would suggest that you address to them a few words on Hypocrisy. At the present moment the Anglo-Saxon world (both England and America) has carried hypocrisy to a fine art and the Nation's life political, social and moral rests largely on the suppression of all truths which do not flatter the Nations' good opinion of themselves. The moral of Resurrection, as we understand it, is precisely the opposite - i.e. - its aim is to destroy Society's pretences, its self flattery, [...]. Should you send a message to the American People on Hypocrisy, or on any other subject you desire, in connection with Resurrection. I will forward it with the article to the American Publisher of Harpers' Magazine, and send you a proof. My wife I think is known to you as the English translator of one of your works "The Kingdom of God is Within You”, and also of Turgenev's Novels and Tales. (Manuscript Department of the State Museum of L. N. Tolstoy, f. 1-216/30) 
On the envelope, there is a note by an unknown hand: “Отв. Л. Н. 21 июня 1900,” which means: “Answered L. N. 21 June 1900.” On that day, Tolstoy wrote his famous address to the American nation, which was published in one of the American magazines. Addressing Edward Garnett, Tolstoy wrote:

\footnotetext{
I thank you for your letter of June $6^{\text {th }}$. When I read it, it seemed to me impossible that I could send any message to the American people. But thinking over it at night, it came to me that if I had to address the American people, I should like to thank them for the great help I have received from their writers who flourished about [the] fifties. I would mention Garrison, Parker, Emerson, Ballou and Thoreau, not as the greatest, but as those who I think specially influenced me. Others names are: Channing, Whithier, Lowell, Walt Whitman - a bright constellation, such as is rarely to be found in the literatures of the world. And I should like to ask the American people, why they do not pay more attention to these voices (hardly to be replaced by those of Gould, Rock[e]feller and Carnegie) and continue the good work in which they made such hopeful progress. (Tolstoy 1928-1958, 72: 396-397)
}

Thus Tolstoy, thanks to Constance Garnett, expressed his gratitude to the American writers. He completed this letter with words of thanks to Constance Garnett: "My kind regards to your wife, and I take opportunity of once more thanking her for her excellent translation of the 'Kingdom of God Is Within You"' (Tolstoy 1928-1958, 72: 397).

The last time Constance Garnett turned to Tolstoy was in 1922, when she translated his article "Christianity and Patriotism." It was highly symbolic that at the beginning and at the end of her career there was a religious and philosophical work by Tolstoy. The list of her translations of Tolstoy's works is impressive, and she is still known as one of the best translators of this Russian writer and thinker. She was regarded as a brilliant translator by Joseph Conrad, Katherine Mansfield, F. Scott Fitzgerald, Ernest Hemingway, and many other British and American writers. Several generations of British and American readers were acquainted with War and Peace thanks to her translation. The recognized Russian scholar Tamara Motyleva wrote about Garnett's translation of War and Peace as the translation which survived many others $(1978,94)$.

\section{Works cited}

Arnold, Matthew. “Count Leo Tolstoi.” Fortnightly Review 252 (December 1887): 783-799. Biblioteka L'va Tolstogo v Yasnoi Polyane [Library of Leo Tolstoy at Yasnaya Polyana]. Vol. 3. Knigi na inostrannykh yazykakh [Books in Foreign Languages]. Tula: Izdatel'sky Dom Yasnaya Polyana, 1999.

Chukovsky, Korney Ivanovich. Vysokoe iskusstvo [High Art]. Vol. 3. Moscow, 1966.

Garnett, Constance. “The Art of Translation.” Listener 30 January 1947: 195.

Garnett, David. The Golden Echo. London: Chatto \& Windus, 1953. 
Garnett, Richard. Constance Garnett: A Heroic Life. London: Sinclaire-Stevenson, 1991.

Gifford, Henry. “On Translating Tolstoy.” New Essays. Ed. Malcolm Jones. Cambridge, 1978. 17-38.

“Interview with Kyle S. Crichton.” World [New York] 11 October 1925, sec. 3: 4m.

Kenworthy J. C. A Pilgrimage to Tolstoy. Croydon: The Brotherhood, 1900.

Kenworthy, John Coleman. Tolstoy: His Teaching and Influence in England. London: Clarion:

Simpkin, Marshal \& Co, 1901.

Kenworthy, John Coleman. Tolstoy: His Life and Works. London and Newcastle upon Tyne: Walter Scott, 1902.

Maude, Aylmer. The Life of Tolstoy: Later Years. London: Constable, 1910.

May, Rachel. The Translator in the Text: On Reading Russian Literature in English. Evanston: Northwestern University press, 1994.

Motyleva, Tamara. “Voina i mir" za rubezhom [War and Peace Abroad]. Moscow Sovetsky pisatel', 1978.

Tolstoy, L. N. Polnoe sobranie sochinenii [Collected Works]. 90 vols. Moscow and Leningrad: Khudlit, 1928-1958.

Turner, Charles. Count Tolstoy as Novelist and Thinker. London: Trübner, 1888.

Galina Alekseeva, $\mathrm{PhD}$, is head of the Academic Research Department, State Museum-Estate of Leo Tolstoy at Yasnaya Polyana; ICLCM (ICOM) President (since 2013); a member of the Slavic Research Group at the University of Ottawa (Canada); and vice-chairman of the Academic Council at the State Museum-Estate of Tolstoy at Yasnaya Polyana. She is the author of more than 120 academic publications in Russian, English, Greek, Italian, Chinese, Finnish, Turkish, and other languages, including the book American Dialogues of Leo Tolstoy (in Russian - 2010) and Books in Foreign Languages, volume 3 of an annotated catalogue of Tolstoy's personal library (also in Russian - 1999). 